\title{
The Duration of Unemployment in Russia'
}

Louise Grogan, Dept. of Economics, University of Amsterdam and Tinbergen Institute Amsterdam, Keizersgracht 482, 1017 EG Amsterdam, The Netherlands, tel. 312055135 42, fax. 31205513555

Gerard J. van den Berg, Dept. of Economics, Vrije Universiteit Amsterdam , CEPR, and Tinbergen Institute Amsterdam, de Boelelaan 1105, 1081 HV Amsterdam, The Netherlands, tel. 312044461 32, fax. 31204446020

Abstract: This paper uses the Russian Longitudinal Monitoring Survey (RLMS) to assess factors affecting the duration of unemployment and underemployment in Russia between 1994 and 1996. We examine four types of marginalised labour force participants, according to ILO guidelines and to responses from the RLMS questionnaire. We estimate duration models using non-parametric and parametric estimation techniques. Those who have completed higher education are found to have relatively short durations of unemployment and underemployment, regardless of previous job type. Married females appear to have relatively long workless periods. The amount of long-term unemployment amongst the jobless is large and growing over the sample period.

JEL codes: J61, P20, R23

Keywords: unemployment duration, job search, Russia

January, 1999

Thanks to: Charles Bos, Simon Clarke, Micheal Ellman, Siv Gustafsson, Katarina Katz, Alistair McAuley, Bas van der Klaauw, and the University of North Carolina Population Center. All responsibility for errors remains with the authors.

${ }^{1}$ Correspondence Address: Louise Grogan, email: grogan@ @inbinst.nl 


\section{i. Introduction}

On the $22^{\text {nd }}$ of February, 1998, finance and employment ministers from Russia and the Group of Seven leading industrialised countries agreed on an international programme to combat unemployment and stimulate job construction. This agreement marks the first time that leading industrialised countries have pledged economic cooperation in the unemployment fight. It signals increased interaction between Russia and the G7 on social policy questions. However, in order for Russia to be able to join in an international effort to reallocate labour efficiently, much more must be understood about the nature of her unemployment and underemployment problems.

One of the great mysteries of economic transition in Russia has been the lack of an unemployment rise commensurate with the severity of output falls. Given that labour hoarding was generally agreed to be a cause of the very low unemployment rates in the late Soviet era, it might have been expected that the swift price deregulation would lead to a large one-off shedding of workers. Unemployment officially became legal in Russia in 1991, although it was always a small residual phenomenon in the Soviet times. Obsolescence of human capital, caused by the inappropriateness of Soviet-era skills in market economies was generally expected to lead many older workers into unemployment or non-participation.

The Russian labour force has shrunk substantially since transition began, but the official unemployment rate in Russia has remained lower than that prevailing in most of Western Europe. The official Russian statistical agency, Goskomstat, reports that total employment fell by 8.2 million people between 1990 and 1995, with a slight increase in the size of the working-age population. Still, the level of registered unemployed in Russia was only 1.5\% of the labour force in 1993-94 (Standing, 1996).

Due to the extreme diversity within Russia in the economic potential of regions, local analysis may particularly informative. Evidence from the OECD (1997) and the Employment office in Tomsk, Siberia, suggests that the incidence of administrative firings has risen substantially since 1994, while the incidence of job leaving has dropped substantially. In 1994, $51.1 \%$ of those registering at the Tomsk employment office were job leavers, compared to only $4.5 \%$ in 1996. These local statistics indicate the complexity and variable nature of unemployment dynamics in within Russia. 
Unfortunately, registered unemployment statistics are more a symptom of the problems being encountered in reallocating labour in Russia than an indicator that joblessness is low. Registration counts severely underestimate the true level of unemployment, and highlight the fact that the jobless do not make much use of the state employment agency. As well as the de facto jobless, there are perhaps 10-15 times that number of working-age individuals without gainful employment ${ }^{2}$. Many individuals with who are officially employed by an enterprise might not actually report for duty, while others work regularly but do not regularly receive remuneration.

The large size of the informal sector in Russia casts a shadow over all investigations of the Russian labour market using micro-survey data. There are likely individuals who have no desire to have a formal job because they are engaged purely in under-the-table entrepreneurial work, and perhaps others who search less intensively for official work because they are engaged in unreported activities.

Difficulties in categorising the labour force status of individuals are compounded by the perverse effect of policy incentives on employer behavior. According to Roxenborough and Shapiro (1996), the various forms of "Excess Profit Taxes" which have existed in Russia since transition began encouraged firms to keep "ghost" employees on their books. Excess profit tax was calculated as a portion of the average wage bill of the firm, thus encouraging firms to keep employees on at extremely low wages, or sending them on long "unpaid leave". The 1994 form of this tax stated that if the wage bill divided by the number of employees exceeded more than four times the statutory minimum wage, the wage would be subject to a $35 \%$ "Excess Wage Tax". Lowering real wages (which meant simply raising nominal wages less than inflation) also encouraged individuals to leave voluntarily, in which case firms would bear no responsibility for severance pay.

This paper aims to assess the relative importance of demographic, regional, local, and firm-specific factors in determining an individual's labour market status. In doing so, it is hoped to shed light on how the nature of unemployment and underemployment reflects the incentives and constraints of individuals and firms.

We will interpret our results using the search theory of unemployment. This theory is particular attractive in the Russian context because it allows job search to be

\footnotetext{
${ }^{2}$ Estimate of the World Bank advisory to the Russian Ministry of Labour, March 1998.
} 
seen as an investment activity. Thus the gains from a spell of unemployment may outweigh the losses if the individual eventually finds a better-remunerated position.

In light of the difficulties regarding the definition, operationalisation, and measurement of unemployment, we perform empirical analyses with different approaches to the issue. In particular, we consider spells of "no work", "no pay", and "no job", as well as spells of unemployment as defined by the ILO, and we estimate duration models for each of these. If a certain explanatory variable (personal characteristics or labour market features) has a similar effect on the lengths of all of these spell types, then this identifies an important indicator of the expected duration until more or less regular work. In such a case, policies addressed at the reduction of the duration until work may focus on the corresponding types of individuals. Since the explanatory variables we use are readily observed, it should not be difficult for government-related institutions to identify these types either.

The paper is organised as follows. Section 2 introduces the Russian Longitudinal Monitoring Survey (RLMS), the panel on which the empirical analysis is based. In section 3 we discuss the unemployment definitions used in the analysis, and we compare them to ILO standards. We explain why we consider four different types of unemployed and underemployed workers. In section 4 we explain the derivation of unemployment and underemployment spells. Section 5 describes general features of labour force composition in post-communist Russia. We briefly outline the economic theory behinds the models we estimate in section 6 . In section 7 we examine the evolution of the hazard of exit from a spell non-parametrically, and discuss the results of log-rank tests of differences in the survivor functions amongst selected labour market segments. Section 8 is devoted to the results for piece-wise constant hazard models. Conclusions about the relative importance of individual characteristics to unemployment and underemployment durations in are drawn in section 9.

\section{The Russian Longitudinal Monitoring Survey}

\section{i. Data}

The RLMS is a household-based survey designed to capture the effects of economic transformation on the welfare of households and individuals. The survey was 
primarily constructed to answer policy-related questions regarding poverty, health, nutrition, and economic status. The first RLMS panel covers the years 1992 to1994, and the second years 1994 to 1996 . The 1994-1996 rounds of the survey were financed largely with grants from the United States Agency for International Development (USAID). Interviews were carried out in the fourth quarter of each year. Recentlypublished articles using the first wave of the RLMS (1994) panel have focused on topics such as monitoring nutrition during reform (Popkin et al. (1996)), iron intakes amongst demographic groups, induced abortion, and poverty (Mroz and Popkin (1995)).

The RLMS is unique in its coverage of the supply side of the post-transition labour market in Russia. The sampling procedure makes it a nationally representative sample. In the 1994 survey, 4718 households took part, and individual interviews were conducted with as many adult members of each household as possible. All survey respondents were paid for answering questions. The household response rate was above $80 \%$ in the first wave (1994). Interviewers returned to addresses in subsequent rounds, and they did not follow households that had moved residence. Attrition due to moving is low because of generally low labour mobility in general in Russia.

\section{ii.Variables}

The data set for on which this empirical analysis is based comes from individual records of the second RLMS panel. The individual-level survey contains detailed information about occupation, gender, education levels and type, owed wages, unpaid leave, and income from secondary jobs. Information about individual characteristics and working lives was gathered for all household members aged 18 or older. The following analysis includes individuals from age 19 until retirement age (55 for females, 60 for males). ${ }^{3}$

For non-working individuals, information is available on the total work history, including the time at which separation occurred from the last job, registration and benefits receipt from the unemployment service, and the individual's current job search strategies. For underemployed (to be defined below) individuals, information is available on the duration (both elapsed and completed) of unpaid leave spells, and about the

\footnotetext{
${ }^{3}$ Individuals had to be at least 19 at the start of the panel. Selected individuals were required to remain below the official retirement age during the panel period.
} 
elapsed duration of non-payment by an enterprise. Wages are corrected with the CPI for the month prior to the interview.

The selection of individuals for the unemployment and underemployment duration analysis includes only persons who started such a spell sometime after the 1994 interview. This sampling scheme results in a random sample of the inflow into the corresponding state, and as such it precludes initial conditions problems (see Lancaster, 1990). Note that as a result, information about the most recent employment type is available for all individuals. Unemployed individuals are asked to state the elapsed time since they entered this state, while those who are working are asked to state their job tenure. The construction of unemployment spells from answers to RLMS questions is described in detail in section 3.

The RLMS makes use of a ISCO-88 occupational ranking. The ISCO-88 categories are (in general order of skill ranking) Legislators, Senior Managers and Officials; Professionals; Technicians and Associate Professionals; Clerks; Service Workers and Market Workers; Skilled Agricultural and Fishery Workers; Craft and Related Trades Workers; Plant and Machine Operators and Assemblers; and Unskilled Workers. Workers in unskilled occupations act as the reference group throughout the analysis.

The RLMS divides the sample into eight distinct regions: Moscow and St. Petersburg Metropolitan Areas; the North North-West Region; the Volga Vyatski and Volga Basin Region; the Urals; Eastern Siberia and the Far East; the North Caucuses; Western Siberia; and the Central and Central Black Earth Region. Previous analysis (see Grogan 1997a), has shown that the Western Siberian region has the highest rouble wages of these regions. For this reason Western Siberia is the reference region throughout the analysis.

\section{Defining unemployment in Russia}

In 1982 the International Labour Organisation introduced a new set of standards for defining employment and unemployment, the relation between income and employment, and the economically active population (Rao and Mehran, 1985). The definition of unemployment explicitly aims to facilitate international comparability 
by allowing for differences in labour market structure of less and more developed countries.

The three criteria of the ILO's standard definition are that an individual is without work, currently available for work, and seeking work at the time of interview. The resolution states,

"In situations where the conventional means of seeking work are of limited relevance, where the labour market is largely unorganised or of limited scope, where labour absorption is...inadequate, or where the labour force is largely self-employed, the standard definition of unemployed may be applied by relaxing the criteria of seeking work." (Rao and Mehran, 1995).

In the section below, we discuss the application of the 1982 ILO guidelines to the Russian labour market and to RLMS data. Central to our considerations is idea that job search intensity, availability for work, and unemployment spell lengths are affected by the formal nature of the employee-enterprise link. We explain how we account for those on unpaid leave, those experiencing wage arrears, the embryonic nature of the Federal Employment Service, the informal sector, and the constraints of the RLMS questionnaire. In line with the empirical literature on duration models, individuals who attrit from the panel, and who are observed to be in unemployment, are considered to have right-censored (incomplete) spells of unemployment. In the final part of this section, propose four categories of unemployment to be used in the duration analysis.

Individuals considered in the duration analysis are between age 19 and normal retirement age in the 1994 round of the RLMS. As explained before, we exclude spells ongoing at the time of the 1994 interview. Thus we have 3306 individuals, some of whom experience no work interruptions before the 1996 round. Comparisons of results for the flow and the of individuals unemployed at the 1994 interview is contained in Appendix A.

Between the 1994 and 1996 interview, 465 of the 3306 individuals were lost to attrition. We account for the unemployed who attrit between the 1995 and 1996 rounds by including information about the non-work spell as a right-censored duration. 
This is only a partial account for attrition. We cannot account for 1994-1995 attrition in this way, as no information about possible unemployment spells exists for these people. One concern is that individuals who attrit between the 1994 and 1995 waves may have different probabilities of experiencing non-work spells than those who are in our sample.

The importance of including discouraged workers in the analysis is evident from the fact that $85 \%$ of non-workers who did not search in the month before the 1995 interview reported that they want a job. In the 1996 interview, the proportion was $83 \%$. The second of the four categoristions, "No Work" includes all individuals who non-working individuals who reported that they want a job.

\section{i. Unpaid leave}

The ILO's 1982 guidelines suggest a modification of the definition of unemployment in order to exclude individuals who are temporarily absent from their jobs. According to the 1954 definition of unemployment, individuals who are temporarily or indefinitely laid-off without pay may be considered to be unemployed. In the 1982 definition, only laid-off workers without certain recall to their positions can be included as unemployed in the restricted definition.

Given that it is widely believed that unpaid leave has been applied as a substitute for unemployment in Russia (see for example Standing, 1996), we attempt to account for such cases in defining our sample of unemployed.

It should be noted that partially-paid leave was more prevalent amongst respondents in the RLMS surveys than unpaid leave. At the time of the 1995 survey, $0.7 \%$ of workers were on unpaid leave, while $1 \%$ were on partially-paid leave. Unfortunately, no information was gathered about the length of completed spells of partially paid leave. We do know, however, that many of those on partially paid leave at the time of interview were also owed substantial sums of money from their enterprise. This suggests that many on partially-paid leave were not actually receiving payment during leave. ${ }^{4}$

\footnotetext{
${ }^{4}$ In the Kamaz truck factory in Naberszheny Chelny, for example, workers officially earn $2 / 3$ of their salary when on leave. However, this salary exists on paper only. Instead of receiving payment, part of the debt to workers is paid as coupons for the company store. This store stocks little more than bread rolls, milk, and sour cream, at prices three times that of the local market.
} 
The RLMS questionnaire does not allow us to make a distinction between short-term and undetermined unpaid leave periods, as required by the 1982 ILO unemployment definition. Even when it is known whether a completed spell of unpaid leave resulted in a separation, return to the old job, or transition to a new job, we have no information about how individuals viewed their lay-offs during unpaid leave spell. In the current economic situation, many workers who were told that they could return at a specified date would likely not have expected this to occur.

Given the impossibility of distinguishing the "temporarily" and "permanently" laid-off, we treat all unpaid leave spells alike 5 .

\section{ii. Wage Arrears}

The 1982 ILO unemployment definition was designed to complement the definition of employment, and thus to identify the economically active population. According to the employment criteria, being "at work" explicitly involves remuneration in cash or kind during the reference period. ${ }^{6}$ Individuals experiencing spells of non-payment may not be considered ILO-employed.

Thus, individuals who work but have not received wages during the reference period or for longer do not strictly comply with either the ILO-employment or the ILO-unemployment criteria. While little is known about the frequency with which owed wages are actually paid, it is known that the stock of arrears in the population increased by $40 \%$ between 1994 and 1996 (Lehmann et al. 1988). This suggests that some workers in arrears are never paid.

We view the existence of wage arrears as one of several indicators of hidden unemployment in Russia. For this reason, we include formally employed individuals

\footnotetext{
${ }^{5}$ Spells of unpaid leave are determined by responses to the question "How many calendar days, without a break, did this leave last or has it lasted?" Completed and right-censored spells are possible.

${ }^{6}$ According to the ILO, employed persons are those "above a specified age" who, during the reference period are either:

i. At work, performed some work for wage or salary during the reference period.

ii. Generally work, but were ill or injured; on holiday; on strike; on training, maternity, or parental leave;

iii. Persons who performed some work for profit or family gain (in cash or goods) during the reference period

iv. Working with an enterprise but temporarily not at work during reference period for a specific reason.
} 
who experience wage arrears as a subgroup in the following analysis of unemployment spells. ${ }^{7}$

\section{iii. The Federal Employment Service}

From 1988 onwards, the economy of the USSR was in dramatic recession (Ellman and Kontorovich (1992)), and the Soviet regime recognised that unemployment was inevitable. The 1991 "Employment Act" in the USSR led to the development of a Federal Employment Service (FES). By the end of 1994 there were 2300 labour exchanges in Russia (Standing, 1996).

Few of the workless bother to register as unemployed. Firms are obliged to register all vacancies with the FES, and to make use of the FES in recruitment. In fact, they seldom do. In the 1991 Russian Labour Flexibility Survey (RLFS), 2/3 of firms used advertisements to recruit workers, and only $14 \%$ relied directly on the FES to fill vacancies. According to Standing and the 1994 RLFS, only 2/3 of firms registered their vacancies with the FES, less than in 1991.

Standing (1996) explains several reasons why a relatively small number of unemployed individuals register. Despite their rapid emergence, FES offices are still few and far between. Many firms fail to inform dismissed workers of the need to register (they can then avoid severance pay), there is a low probability of getting a job via the FES, there are strict criteria for receiving any benefits, and any benefits received are very low ${ }^{8}$.

The region-specific nature of FES funding is a key reason why benefit arrears were an average of nine months as of March, 1998 . Funds for benefit payment are collected by levies on local employers. Thus high-unemployment, low activity regions have relatively little funds to be allocated amongst a relatively large number of individuals.

\footnotetext{
${ }^{7}$ The RLMS questionnaire does not include a question about completed spells of wage arrears. All of the observations are of right-censored spells, thus of the stock.

${ }^{8}$ Standing (1996) estimates these benefits in 1996 at about $10 \%$ of the funds necessary for survival.

${ }^{9}$ Thanks to the World Bank Advisory to the Ministry of Labour, Moscow for this information.
} 
For these reasons, labour force surveys give a clearer indication of true unemployment levels than FES statistics. In 1994, the Russian LFS reported unemployment at 7.4\%, and in August 1996, 9.2\% (Goskomstat, 1996). Table 1 indicates the low and declining use of the state employment agency amongst the RLMS 1994-1996 sample. It also shows that the female unemployed are far more likely to be registered than male.

(table 1 about here)

A major reason for non-registration may be that individuals who are registered have a relatively low likelihood of benefits qualification. The above table seems to indicate that women find it easier than men to qualify for benefits. This might explain part of their higher registration rate ${ }^{10}$. The other key role of the state employment agency, that of matching firms and workers, seems also to be little regarded by the unemployed. Table 2 gives an indication gives of the ways in which unemployed individuals in the RLMS searched for new jobs.

(table 2 about here)

At least amongst RLMS repondents, the importance of friends, and direct applications to enterprises, seems dominant. Only about half of respondent used the FES for job finding, and less made use of private agencies in the month prior to interview.

The two tables above confirm that official unemployment statistics are of little use in unemployment analysis, and highlight the ineffectiveness of the state employment agency as a mechanism for matching workers to vacancies. If unemployment in Russia is low, it is not due to the strength of government response.

\footnotetext{
${ }^{10}$ As economic depression deepened in the dying days of the Soviet Union, some prominent Soviet demographers and economists advocated cutting the employment of women. This was seen as a way of boosting sagging birthrates, and of minimising the inevitable unemployment that would result from restructuring (Standing, 1996). Although no official policy to get women "back to the home" was undertaken, unemployment registry statistics from the beginning of the transition did seem to suggest that females were more likely than males to become jobless. In fact, as Standing (1996) points out, this is simply because that, once unemployed, women were $50 \%$ more likely than men to register with the unemployment service. Standing's evidence from a job-seekers survey carried out in 18 districts in 1993-1994 suggested that women were more likely to be offered job retraining, more likely to leave the unemployment register to jobs, and were more likely to have shorter periods of unemployment.
} 
We originally hoped that it would be possible to distinguish between respondents who were registered as unemployed and receiving benefits, and those who are not. However, the panel aspect of the analysis makes this impossible. For those who experienced unemployment spells between interview periods, we do not observe whether they were registered at the time of their spell.

\section{iv. The Informal Sector}

According to a strict interpretation of ILO unemployment criteria, individuals who engage in informal activities for remuneration should not be considered unemployed. In Russia, this would likely be a very large portion of those "without a job", because of the effective absence of unemployment benefits. Unfortunately, it is not likely that a household survey such as the RLMS accurately captures the extent or the nature of informal sector activities. It is impossible to know whether these activities were the choice in the face of formal sector opportunities, or simply short-term survival measures taken by those who would prefer the stability of a formal workplace.

We do not exclude individuals on the basis of informal sector activity for two reasons. Firstly, the likely underreporting of the activity makes the relevant variables in the RLMS unreliable. Secondly, we assume that most individuals would prefer the relative security attached to a formal workplace, and would accept a reasonable job offer. A desire for enterprise attachment might be particularly strong amongst Russian workers, who have spent most of their working lives attached to all-providing enterprises $^{11}$. In the 1994 sample, $14 \%$ of non-working individuals of working age reported engaging in individual economic activity in the month prior to the RLMS interview.

\section{v. The RLMS questionnaire}

Individuals in the RLMS were asked about their employment status in three different questions, placed at the beginning, middle and end of the interview. The first question of the interview, "Tell me please, do you work now?", could be answered with "yes", " maternity leave or leave for caring for a child under three", "other paid leave", "unpaid leave" or "no". In the middle of the interview, individuals were again

\footnotetext{
${ }^{11}$ Thanks to Katarina Katz for helpful discussion on this point.
} 
asked if they "currently work", with the possible answer being affirmative or negative. At the end of the interview, individuals were asked to label one "primary occupation at present" from a choice of fourteen. ${ }^{12}$

In order to distinguish between individuals who would like a job and those who are non-participants, we use responses to the question "Did you go anywhere or see anyone looking for a job in the past 30 days?" Responses to this question were compared to the answer to the question "Would you like to find a job?" This question was assumed to identify individuals who had become discouraged after non-successful search, but who are still ready and available for work.

Although the RLMS contains responses to a question in which a person is asked to describe himself as working, unemployed, a housewife, disabled, a pensioner, amongst other things, this question was not used to distinguish unemployed from nonparticipants. Given the stigma still associated with unemployment in Russia, it was thought that many would prefer to call themselves "housewives", "retired", of "disabled", when in fact they would be willing to take a job at a wage above their reservation. Table 3 illustrates just how important the difference is between individuals who consider themselves unemployed, and those who would be considered unemployed according to the ILO definition.

(table 3 about here)

Many females who consider themselves housewives would actually be unemployed according to an ILO-style definition, but not according to respondent's self-definition, or that of Foley (1997) in an earlier study of Russian unemployment. Foley uses individual's self-classification as the basis for his determining who was unemployed in the 1992-1994 rounds of RLMS. According to Foley's definition, only those who described themselves as "not working, looking" would be considered

\footnotetext{
${ }^{12}$ One of the following responses (besides non-response) was possible: High school or vocational school student; A university or technical school student; unable to work for health reasons, disabled; retired and not working; on maternity leave; on official leave for taking care of children under age three and not interrupting employment; a housewife, caring for other family members, raising children; temporarily not employed for other reasons and looking for a job; temporarily not employed for other reasons and don't want to work; a farmer; an entrepreneur; working at an enterprise, organisation, collective farm, state farm or cooperative; working at other than an enterprise, organisation, collective farm, state farm, or cooperative; other (specify).
} 
unemployed. In fact, as Table 3 shows, many such people did not search for a job in the month prior to the RLMS interview.

The 1982 ILO definition of unemployment allows for the inclusion of students, housewives, and other non-working groups if they satisfy the three basic criteria above. This provision allows the definition to overcome possible stigma effects of being unemployed, which may lead non-working, searching individuals to label their labour force status differently. It is expected that such stigma effects would be particularly large in a country where unemployment was unheard of before 1991 .

\section{vi.Subgroups of the RLMS sample}

Our sample of unemployed and underemployed individuals is subdivided in four ways. The core, "ILO" sample is of individuals who reported no work in the first question of the 1994 or 1995 interview, and who reported that they had been engaged in job search in the month prior to the interview. ${ }^{13}$ The "No Job" group extends this sample to include non-workers who did not report search but want a job. By augmenting this with the individuals experiencing unpaid leave, we obtain the "Not Working" group. Finally, the sample is augmented by the addition of individuals with (incomplete) spells of non-payment, so becoming the "No Pay" group. ${ }^{14}$

It is hoped that these four groupings allow distinctions between these labour market subgroups, and between individuals of different characteristics, to become apparent. We realise, however, that our groupings of unemployed and underemployed are not exhaustive. Individuals who become jobless in communities where they know there are no work opportunities might discount the idea that they want a job. Underemployment is suggested by administratively-reduced reduced work hours and consistently low remuneration, as well as by the forced unpaid leave and non-payment considered here. However, these issues cannot be addressed in the framework of a duration analysis based on household survey data.

\footnotetext{
${ }^{13}$ Individuals experiencing spells between interviews were assumed to have searched, because they did find jobs before the next round.

${ }^{14}$ It is possible for individuals to have more than one spell in the data. When this occurs, a random draw is used to choose one of the spells. This selection avoids the problem of correlations between observations.
} 


\section{Creating Spell Files}

The duration analysis includes only individuals who left jobs after the 1994 round and before the 1996 round of the RLMS survey. Because our primary interest is in the flow through unemployment, those who left jobs before Round $\mathrm{V}$ are not included in the main analysis. Because we are more likely to observe longer unemployment spells, the stock of 1994 unemployed contains individuals with spell length generally greater than the mean. Appendix A compares results obtained from the 1994 stock of unemployed with those of our 1994-1996 flow sample.

The recovery of short spells of unemployment from the original data set is complicated by the fact the RLMS does not include questions about completed job, unemployment, or non-participation spells between interviews. Spells of non-work between interviews could be partially recovered by looking at differences in the reported duration of the present job at each interview.

If the difference in interview dates between the two years did not match the difference in reported job duration between interviews to within one month of accuracy, it was assumed that a work interruption took place. Where a work interruption took place between interviews, it was assumed that individuals spent at least some of this time in unemployment, and did not move to non-participation. Given that the non-work spell ended in employment, it is assumed that some job search must have occurred.

It is impossible to determine exactly how much of this unexplained time between interviews is actually non-work, or even to distinguish observations by a rule based on personal characteristics. We have no information on the number of weeks worked by the individual in the year of interest, so cannot create an upper bound for the fraction of "unexplained time" spent in unemployment. We know only about one event which occurred between interviews.

Several different specifications were made to assess the sensitivity of the estimates to assumptions about what individuals did during "unexplained periods". Results regarding duration dependence and the influence of personal characteristics were found to be robust under several different division rules for "unexplained time" 15

\footnotetext{
${ }^{15}$ Assumptions about the division of "unexplained time" between employment and work include:

i. $\quad$ no time spent in unemployment

ii. $\quad 50 \%$ of time spent in unemployment
} 
and to different assumptions about the distribution of unemployment spells. In what follows, we will focus on results in which the work-unemployment division of unexplained spells is 90/10. ${ }^{16}$ Although the simplicity of such a rule precludes distributional considerations, other feasible rules would be equally arbritrary. We are aware that not accounting for the distribution of unexplained time may create spurious spikes in the observed hazard, since individuals who make several transitions between interviews will be coded as having only one spell. Still, our division rule gives mean unobserved spell durations which are closest to that reported by Goskomstat(1996) for age and gender groups.

Inconsistency of responses regarding unemployment duration would occur if individuals unemployed in 1995 or 1996 systematically reported elapsed durations which were at odds with their responses (state, elapsed duration) in previous rounds. Amongst the search unemployed, only 8 of 86 respondents unemployed at the 1996 interview reported durations which were inconsistent with their reported status in the 1995 interview, and only 6 of 64 had an inconsistency between 1994 and 1995. Most of these inconsistencies were less than month in magnitude, and as such the observations were retained.

Graph 3 illustrates the possible movements of individuals in our sample through spells of worklessness. The thick lines represents imprecisely observed spells, while the thin lines represent spells for which precise duration is known. It is possible that several short unobserved spells occurred during "unexplained time", but we abstract from this possibility.

(Graph 3 about here)

\footnotetext{
iii. $\quad 80 \%$ of time spent in unemployment

iv. $\quad 100 \%$ of time spent in unemployment

v. randomisation of percentage of time spent in unemployment

Results of sensitivity tests are available from the authors on request.

16 This was judged to be more exact than simply excluding spells between interviews, because individuals with relatively long unemployment durations are more likely to be unemployed at a given interview date. Although we are unsure of spell length, the inclusion of "unexplained time" spells is informative about the parameters of interest and the dynamics of the hazard function.
} 


\section{Labour Force Participation}

Changes in labour force participation over the sample period are of interest because those who exit the labour force are likely to have different characteristics from those who enter the jobless pool. Table 4 below suggests that the distribution of individuals amongst various labour market states was relatively stable in the sample period.

There are more working-age males than females in jobs, although the gap declined to only $6.4 \%$ over the sample period. The female jobless are less likely than the male to have searched in the month prior to the interview, although there is no gender difference in the proportion of workless who report that they would like a job. This result suggests that gender-based differences in search intensity may be of key importance in explaining male-female differences in expected unemployment durations. $^{17}$

(Table 4 about here)

The proportion of non-workers who are uninterested in obtaining jobs remained at about $25 \%$ over the course of the panel. Thus it seems that the majority of individuals who lost jobs during this period flowed into unemployment rather than out of the labour force. It is of interest to compare the information about unemployment incidence and duration in the 1994-1996 rounds of the RLMS with that from earlier rounds of the survey. In his analysis of the 1992-1994 RLMS panel, Foley (1997) observed that unemployment is very high amongst under-21s, and relatively high amongst the 21-29 age group. Gender differences in unemployment incidence did not seem important, although Foley reports that women have longer expected unemployment durations. While the higher educated have lower unemployment incidence, they have higher than average durations.

Our data concurs with that of Foley in finding a relatively high incidence of unemployment amongst the young, and a lower-than-average incidence amongst the

\footnotetext{
${ }^{17}$ Even if gender-based differences in search intensity appear to be a major cause of gender differentials in expected duration, the possibility of discriminatory hiring practices should not be discounted. Search intensity can be seen as an endogeneous outcome: if there are relatively few jobs out there that females feel they will be considered for, then their optimal search strategy will be less intensive than that of males.
} 
most highly educated. Table 5 shows the incidence of unemployment amongst different subgroups of the working age population.

(Table 5 about here)

Due to differences in the definition of unemployment used however, and Foley's lack of account of spells between interviews, our results concerning expected durations are not be directly comparable.

\section{Theoretical Background}

We interpret our results according to search theory, which explains how individuals behave when they are looking for work, and about how firms get matched to new employees. The unemployed are assumed to draw offers from a wage offer distribution. Individuals know the wage offer distribution in their local market, but they do not know in advance the location of job offers or the corresponding wage offers.

The expected length of a worker's unemployment durations can be modelled in a way which takes simultaneous account of the effort a worker takes to find a new job, and the value firms associate with an individual job applicant. Firm and worker behavior is based on expectations of individual gain, and will affect the rate of arrivals of job offers. (see Devine and Keifer (1991)).

The only ways the individual can influence his spell duration are by varying the intensity of job search, or by changing the lowest acceptable wage offer. In the simplest search theory models, job offers are made to a worker according to a Poisson process. The attractiveness of a job offer is measured by the wage. Job/wage offers received during a spell of unemployment are independent realisations of a known wage offer distribution, $F(w)$, with finite mean and variance.

A worker wishes to maximise the expected present value of all future income, appropriately discounted. The individual receives a constant stream of income, b, while unemployed. When faced with an offer the worker must accept or reject the offer immediately, under the assumption that the new job will last forever. 
Suppose that the search environment is stationary, i.e. that all structural parameters are constant over time (see Van den Berg 1990 for details). It can be shown that the lifetime income-maximising individual's reservation wage $w^{r}$ is characterised by

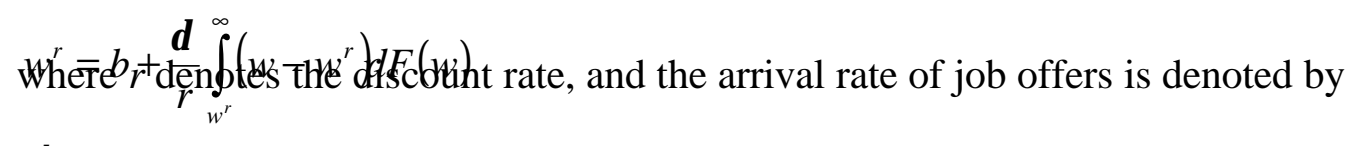
$\delta$

The reservation wage is a weighted average of the benefit level, and the mean acceptable wage offer.

Taking first derivatives, it can be seen that the reservation wage increases in the level of benefits, decreases in the discount rate, and increases in the arrival rate of job offers. The above description allows basic predictions to be made about spell lengths. The instantaneous probability of exit is decreasing in the level of benefits, and increasing in the individual's discount rate. The worker's expected wage in the new job is also increasing in the benefit level, decreasing in the discount rate, and increasing in the job offer arrival rate.

The probability that an individual accepts the job offer when it arrives is given by the probability that the wage offer is at least equal to the reservation wage:

$$
1-F\left(w^{r}\right)
$$

The transition rate from unemployment to employment equals the product of the arrival rate of offers and the probability that an offer is acceptable. So

$\pi=\delta *\left(1-F\left(w^{r}\right)\right)$

The stationarity assumption implies that the transition rate is constant within a spell, and thus that the spell duration has an exponential distribution. Now let us turn to specifications wher the transition rate varies over the duration.

Human capital theory predicts that a person's productivity depreciates through spells of non work. The individual might search less intensively if the job situation is perceived as hopeless. Employers might have negative perceptions about individuals who have not been working for long periods, so affecting the arrival rate of job offers. On the other hand, as an unemployed individual becomes more impoverished, the likelihood that a given job offer is accepted might rise. 
One major intention of the following analysis is to investigate how the hazard of exit from a jobless spell varies over elapsed duration. For these reasons the all of the specifications adopted in the foregoing analysis will allow the hazard of exit from an unemployment spell to vary over time.

The distribution function

$$
F(t)=\operatorname{Pr}(T<t)
$$

gives the probability that the random variable $\mathrm{T}$ (spell length) is less than some value $\mathrm{t}$.

(Note that here $\mathrm{F}$ denotes the duration distribution and not the wage offer distribution).

The corresponding survivor function is

$S(t)=1-F(t)=\operatorname{Pr}(T>t)$

A hazard function may be defined as

$\lambda(t)=\frac{f(t)}{S(t)}$

denotes $\{$ thet) rate at which spells will be completed at $t$, given that they last until t.

$\lambda(t) \quad$ As is standard in duration analysis, we use the term "failure" to refer to observations for which the spell end is observed.

\section{Non-parametric Duration Analysis}

In order to get an idea of the shape of the distribution of unemployment durations, Kaplan-Meier survival and density functions are plotted, and log-rank tests performed on different population subgroups. The graph below shows the hazard function amongst the subgroup of unemployed searchers, which is the group we call "ILO unemployed" ${ }^{18}$

(Graph 1 about here)

The steep rise in the observed hazard after the ninth month of unemployment can be considered spurious. It is due to the rule which was used to deal with individuals who had spells fully between interviews. One feature of our rule is an equal treatment of the spells of individuals who were employed in two consecutive rounds, and who reported that their new job had begun after the previous interview. A

18 The second of the four categorisations we use, "No Work" includes all individuals who non-working individuals who reported that they want a job. 
substantial fraction of these individuals reported that they had begun their subsequent jobs at most three months before the date of the current interview, thus resulting in a constructed unemployment spell of around nine months. Whereas our rule for the inclusion of unexplained time between interviews is time independent, individuals who report short elapsed durations of jobs are in fact relatively likely to be individuals who made several state changes since the previous interview.

As a result of the spurious spike in the hazard, we should not take duration dependence results in our estimations too seriously. However, the shape of the hazard in the first six months may give a rough guide to the true path of duration dependence amongst the Russian population.

Graph 2 plots the survivor function over time. The probability of surviving beyond 10 months is about $15 \%$.

(Graph 2 about here)

We also assess the importance of various personal and environmental characteristics to duration non-parametrically. It is important to note that the spurious spike in the nonparametric estimation of the hazard (see Graph 1) will not distort the covariate effects of principal interest in our analysis.

To test for covariate effects we performed Weibull estimations on a modified data set in which a fraction of individuals with 9 to 10 month durations were recoded as having the median duration of completed spells which spanned an interview date. The signs, orders of magnitude, and significance of the coefficients was very close to that obtained in the Weibull analysis of Appendix C. We also found strong positive duration dependence in the modified data.

Table 6 presents the results of log-rank tests of the survival functions of a selection of labour market segments, performed for each of our four groups of marginalised labour force participants.

(Table 6 about here) 
From the above it is evident that individuals who have completed higher education, and those in professional occupations, experience significantly different (lower) durations than those who have not. Also, non-workers in the metropolitan areas of Moscow and St. Petersburg have different (lower expected duration) distributions from those in other parts of Russia. These results are consistent over the four subgroups of marginalised labour force participants.

Just as interesting as the factors which appear to be significant in the nonparametric specification, are the factors which do not, and those who appear significant only amongst certain groupings. Marital status, the completion of vocational education, living in a small town, and the presence of a Federal Employment Service office in the individual's community appear to have negligable effects on the path of the survivor function, according to the simple log-rank test.

The effects of age and gender are not significant amongst the jobless, but become so when the grouping is enlarged to include those on unpaid leave and those in wage arrears. In both of the last two cases, younger workers (those under 25) have relatively long periods of labour market marginalisation. In the two larger groupings females have steeper declines in the survivor function, suggesting that they are more likely to escape such situations of marginalisation quickly.

\section{Piece-wise Constant Hazard Model}

The piece-wise constant hazard model is a partially parametric explanation of differences in duration distributions amongst labour force groups. It is used here as a way of assessing differences between our four subgroups in the direction of the hazard at different points in time, while controlling for differences in the observable characteristics on individuals, as well as unobservable herterogeneity in the data. Unobserved herterogeneity is herterogeneity in skills of individuals, and possibly their intensity of search, which is not measured by interviewers or variables in the data set.

We fit a piece-wise constant hazard to each of the four labour market groups under consideration. The hazards are assumed to be constant within each quarter in the 
first year of duration, and to be constant thereafter. Thus, between each quarter hazards will generally be different.

(Table 7 about here)

Severance pay benefits expire after 2 or 3 months in Russia, provided they are claimed by the dismissed worker. If the expiry of such benefits has an impact on search intensity, we would expect relatively high hazards in the first three months of duration and shortly afterwards. Table 8 shows that, as with the non-parametric plot of the hazard function (see Graph 1), there appears to be no such tendency. The expiry of severance pay appears to have a negligable effect on hazards of exit from unemployment, largely because most individuals do not claim benefits.

Given two mass points, the probability values and their standard deviations show that unobserved herterogeneity is not important in any of the four grouping of marginalised workers here considered. This corraborates with Foley(1997), who finds that unobserved herterogeneity is not of significant importance in the 1992-1993 rounds of the RLMS.

It is important to stress that the covariate results in Table 7 are invariant to the aspects of data manipulation that lead to the spurious pike in the hazard at nine months. Duration dependence estimates will only be affected for the interval in which the spike is located. The piece-wise constant specification shows substantial positive duration dependence amongst each of our four marginalised groups within the first 6 months of unemployment.

Our coefficient values, like the hazard parameters, generally concur with the results obtained in the previous non-parametric analysis. Those who have completed higher education, those who reside in Moscow, and females generally have higher hazards of exit from the marginalised labour market states under consideration. Differences in hazards of exit between age groups do not appear significant amongst job searchers, but become so when those on unpaid leave and in wage arrears are included. We find that those living in rural areas have lower hazards of exit from marginalised labour market states. 
Given the known, wide diversity in economic conditions amongst the regions of Russia, it is of interest to compare these aggregated results to local statistics. Data from the statistical office of the Siberian region of Tomsk (Goskomstat Tomsk, 1995) concurs with our results in finding that those with higher education have distinct advantages in finding new jobs. In Appendix B we fit a log-logistic and in Appendix C a Weibull ${ }^{19}$ model of duration distributions, in order to judge the salience of the preceeding results relating to observed individual characteristics.

\section{Conclusions}

The foregoing analysis highlights the importance of accurately defining "unemployment" in the treatment of Russian data. The large differences between an ILO-style unemployment definition and the searching individual's self-classification suggest both that there is a social stigma associated with being workless, and that many people who would like to work do not actively search.

The descriptive statistics relating to the state employment agency, FES, show that the Russian unemployed have little to do with this agency, thus suggesting that administrative data should not be used in looking at unemployment. The insignificance of the presence of an unemployment office on expected unemployment durations suggests that the state employment agency plays no major role in matching workers to vacancies.

The analysis of unemployment durations suggests that highly-educated workers who left jobs after October 1994 have shorter unemployment and underemployment durations than their less educated compatriots. This result contrasts with that of Foley(1997) who finds higher median durations for those with higher education. The unemployment incidence of the higher-educated group is also relatively low. In contrast, those who have completed vocational education do not have significantly different exit hazards from those who have not. As well, the monthly wage received by the individual prior to the separation is generally a poor indicator of expected spell length.

19 For specific information about these models, see for example Lancaster (1990). 
We find no significant differences in hazards of exit from ILO-style unemployment amongst different age groups. This analysis does suggest a higher unemployment incidence for younger workers, but not significantly different expected durations.

Unemployment spells in Russia appear to be short for individuals who lost their jobs after October 1994. The mean completed spell length amongst ILO unemployed is 6.4 months, and the median 6.3. This is far lower than that observed by Foley(1997), but the difference can be easily explained by differences in the sample frame. The low durations can be compared to a mean spell length in Britain of 12.8 months in 1984, following the second oil shock (Layard, Nickell, and Jackman, 1991).

The gender effects we observe are not easily interpretable. On the one hand, females appear to have shorter durations, but on the other hand married females appear to have relatively long ones. It would appear that unmarried females search more intensively than married, or have lower reservation wages, or that marital status counts against females in recruitment. Of female respondents in the 1995 RLMS survey, 74\% are married.

It is important to note that our finding of relatively short expected spell lengths and positive duration dependence amongst the de facto workless does not indicate that the problem of long-term unemployment is diminishing in Russia. The proportion of long-term unemployed amongst the workless increased from .52 in the 1994 sample to .59 in the 1996 . Only $27 \%$ of individuals who were in the jobless stock at the 1994 interview had completed their spell by the last interview of the panel. Unlike in Western European countries, these long-term jobless are not primarily unskilled. The Russian jobless pool appears to be composed of a dichotomy of stayers and movers.

It is important to interpret our results in the context of a labour market which increasingly fails to pay its workers, in which workers are sent on extended leaves with little or no pay, and in which production levels are less than half of their 1991 levels. The low unemployment levels and durations observed in this analysis can be interpreted as an indicator that the massive reallocation of human capital necessary for 
productive efficiency and international competitiveness have not been stimulated by mere price liberalisation and deregulation.

There is evidence that the plot is thickening. On the $26^{\text {th }}$ of March, 1998 the Russian Deputy Minister of Finance announced the elimination of 208000 government employees. The cutbacks, he said, will allow "timely payment for everyone who now works in the national economy". The crash of Russian financial markets in August 1998, and coincident failure of several major Russian banks, has already precipitated large-scale layoffs and a steep rise in the de facto jobless rate. 


\section{REFERENCES:}

Ellman, M. and V. Kontorovich (1998) "Overview”. In: Ellman, M. and V. Kontorovich(ed) The Disintegration of the Soviet Economic System, Routledge Press.1-41.

Employment Service of the Tomsk Region (1997), Statistical contribution to the OECD conference "Regional Approach to Industrial Restructuring in the Tomsk Oblast". Paris June $3^{\text {rd }}-5^{\text {th }}, 1997$.

Foley, M. (1997) "Determinants of Unemployment Durations in Russia", William Davidson Institute Working Paper Series, University of Michigan Business School.

Goskomstat (1996a) Informatsioonyi statistecheskii builletin 13 Nov. 1996.

Goskomstat (1996b). Rossiiskii Statisticheskii Ezhodnik 1996: 93-97.

Goskomstat of Tomsk Oblast (1996). Tomsk Oblast Statistecheskii Ezhodnik.

Grogan, L. (1997) "Wage Dispersion in Russia”, Tinbergen Institute Discussion Paper, Labour, Region and Environment Series, 97-075/3.

Grogan, L. (1998 unpublished) "Worker Characteristics and Unpaid Administrative Leave in the Russian Federation", Department of Economics, University of Amsterdam.

Katz, K (1997, unpublished) "Labour in Transition: Men and Women in Taganrog, Russia” . Department of Economics, University of Goteborg.

Katz, K. (1997). "Gender, Wages and Discrimination in the USSR" Cambridge Journal of Economics 21:24, 431-452

Kiefer, N.M. (1988) "Economic Duration Data and Hazard Functions", Journal of Economic Literature, Vol. 26: 646-679

Lancaster, T. (1979) "Econometric Methods for Duration of Unemployment", Econometrica, 47(4): 939-956

Lancaster, T. (1990), The Econometric Analysis of Transition Data, Cambridge University Press.

Layard R., Nickell S. , and Jackman, R.(1991). Unemployment: Macroeconomic Performance and the Labour Market, Oxford University Press.

Lehmann, H., Wadsworth, J., and A. Acquisti (1998, unpublished) "Grime and Punishment: Job Insecurity and Wage Arrears in the Russian Federation”.

Mroz, T. and B.M. Popkin. (1995). "Poverty and Economic Transition in the Russian Federation”. Economic Development and Cultural Change. Vol. 44: 111-141. 
Newell, A. and B. Reilly (1996). The Gender Wage Gap in Russia: Some Empirical Evidence". Labour Economics 3: 337-356.

Nickell, S. (1979). "Estimating the Probability of Leaving Unemployment", Econometrica, 47(5): 1249-1266

Popkin, B.M., A. Baturin, L. Kohlmeier, and N. Zohoori. (1996). "Russia: Monitoring Nutritional Development During the Reform Period." Edited by Verner Wheelock. Implementing Dietary Guidelines for Healthy Eating. London: Chapman and Hill.

Roxenborough, I. and J. Shapiro (1996), "Russian Unemployment and the Excess Wage Tax", Communist Economies and Economic Transformation, Vol. 8 No.1: 5-28

Van den Berg, G. (1990).”Non-Stationarity in Job Search Theory", Review of Economic Studies 57: 255-277.

Van den Berg, G. and Van der Klaauw, B. (1998 unpublished). "Combining Micro and Macro Unemployment Duration Data", Vrije Universiteit Amsterdam . 


\section{Appendix A:Comparison of 1994 Stock of Unemployed and 1994-1996 Flow Sample}

While the main focus of the paper has been on individuals who experienced a spell of worklessness in the period following the first interview of the panel, we are interested in the extent to which our results may be generalised to all respondents in the RLMS questionnaire.

A priori, we expect individuals who are observed to be without work at the 1994 interview to have longer expected durations than those in the 1994-1996 flow sample: Longer durations are more likely to be observed at any point in time. We expect the flow sample to have stronger labour force attachment that that of the 1994 stock, as they will be relatively unaffected by any stigmatisation effects of being longterm unemployed.

To compare our stock and flow samples we construct a panel which includes only individuals who were observed to be not working in the initial interview. When we account for attriters as right-censored spells, this gives us a sample of 1005 observations. We then eliminate individuals who have never worked (202), those whose workless spell began before 1991 (when unemployment officially became legal) (143). Those who answered negatively to the question "Do you want a job?" (162) were excluded, as were 37 individuals who provided inconsistent responses to duration-related questions.

Primarily because of our assumption that the sample containing a larger number of long-term jobless would have relatively more non-searchers, we decided not to invoke the search criteria in our comparison. Only 53\% of our 633 remaining individuals from the 1994 workless stock reported search in the month prior to the 1994 interview.

(Table 8 about here)

A key similarity between our 1994 sample and that of the 1994-1996 flow is that neither finds negative duration dependence in the sample. For our 1994 sample the $95 \%$ confidence interval locates roe between .95 and 1.23 , suggesting neutral or small positive duration dependence. 
We find more females, and more individuals with higher education in our 1994 sample than in the flow. As well, we appear to have more youth unemployed in the 1994 stock.

The regression results are generally consistent between the two samples in size and significance. Those in the 50-59 age group have significantly longer durations amongst the stock and the flow. In both the stock and the flow, the youngest workers appear to have lower expected durations than any other age group. Married individuals generally have lower expected durations than unmarried, although married females have relatively far higher ones than other females or than married males.

Two significant differences between our 1994 unemployed sample and the 1994-1996 flow sample are in the mean sample duration of joblessness and in the effect of higher education completion on expected duration. Those with higher education who became unemployed prior to the first interview do not have significantly different expected durations from those without higher education. Amongst the 197 completed spells from our 1994 jobless sample, the mean spell duration is 20.2 months. This contrasts with a completed-spell duration of 6.5 from our flow sample.

On the basis of the above comparison, limited though it is to a monotonic distribution of durations, that the qualitative nature of the results drawn for our 19941996 flow sample are not an artifact of the chosen sample frame. 


\section{Appendix B: Log-logistic Model of Duration Distributions}

The log-logistic function was chosen because it allows for non-monotonicity of the hazard function, and for the importance of individual characteristics to differences in the hazard of exit to be assessed. Table 9 shows that the duration dependence parameter allows exit hazards to first rise and then fall over elapsed duration, such as was observed in the non-parametric specification.

(Table 9 about here)

Results using the log-logistic specification of duration distributions mirror those obtained under the piece-wise constant specification. No age group effects on duration are found, and those with higher education have higher hazards of exit amongst all four marginalised groups ${ }^{20}$. In this specification we introduce a gendermarriage interaction term. The gender effect seems to favor females, but married females have lower hazard of exit both than unmarried females and than married males. Given that most females in the sample are married, these results show a net disadvantage to being female.

Duration dependence is also observed to be non-monotonic amongst the larger No Job group of unemployed, which includes discouraged workers. It is first increasing and and then declining, but to a less dramatic extent than amongst the search unemployed.

As in the other specifications, we observe longer durations amongst residents of small towns in the two larger subgroups. This suggests that unpaid leave and nonpayment spells are relatively lengthly in communities of less than 2500 individuals. Analysis of the incidence of unpaid leave during this period (see for example Grogan, 1998) suggests that the incidence of such leave is relatively low in towns which are not regional centers. As such, it cannot be concluded that residents of less important communities are marginalised relative to their compatriots in larger centers. 
Duration dependence is increasing steeply at first amongst the ILO subgroup, then decreasing. A significant difference in the prospects of individuals with and without formal enterprise attachment seems to be in the probability of exit over elapsed duration. The log-logistic specification suggests monotonic decreases in the hazard function over duration for the No Work and No Pay groups. When compared with the results of piecewise constant and Weibull specifications from these groups, it seems logical to conclude that duration dependence is not generally positive amongst these two larger groups. Whereas the de facto jobless appear to lower their reservation wages or increase search intensity as they become increasingly desperate to find a job, those with formal enterprise attachments seem to cling to their old jobs.

Neither the above log-logistic account of duration distributions, nor the Weibull estimation which follows make corrections for unobserved herterogeneity. Positive duration dependence is uncommon in most unemployment duration analyses which do not control for unobserved herterogeneity, because it is generally assumed that the least-employable (for reasons we cannot observe) stay in the pool the longest. However, as our results using a piece-wise constant duration distribution suggest that unobserved herterogeneity is unimportant in our data, our duration-dependence parameters would not be biased.

\section{Appendix C: Weibull Distribution}

Like the piece-wise constant and log-logistic duration specifications, the Weibull specification accounts for the idea that individuals lower their reservation wages or search more intensively as their spells extend. The model is of the proportional hazard type, so the coefficients of variables describe an effect on the hazard which is the same at all elapsed durations.

(Table 10 about here)

Tables 10 presents the results of regression specifications using Weibull distributional assumptions. This specification excludes dummies for the completion of vocation education, previous occupation type, residence in one of the seven regions outside Moscow/St. Petersburg metropolitan areas, and the presence of a Federal 
Employment Service Office in the individual's community. These dummies were found to be insignificant in several trial specifications.

The Weibull specification suggests a significant effect of gender amongst all subgroups. For given levels of observable human capital and occupational characteristics, females appear to have higher hazards of exit in all four marginalised labour force groups. The negative effect of gender on expected durations is particularly strong with the inclusion of individuals on unpaid leave and those in wage arrears. This result contrasts with that of the Kaplan-Meier results for the "ILO" and "No Job" groups, in which gender appeared not to influence survival probabilities. This difference can be explained by the fact that the log rank test of gender differences does not account for marriage effects.

The Weibull specifications suggest important differences in expected durations between married and unmarried individuals, and between females and males who are married. Being married and female appears appears to have a positive effect on duration, despite the generally negative effect of being female on duration. Married males have relatively high hazards of exit from the jobless state.

As in the non-parametric analysis, a strong negative effect on duration of the completion of higher education is observed. No effect of previous wages on duration is observed in any of the four subgroups ${ }^{21}$.

Significant positive duration dependence is observed amongst searching unemployed and amongst the larger subgroup including discouraged workers. This duration dependence is eliminated with the addition of those on unpaid leave and those in wage arrears to the sample.

20 The insignificance of the previous wage in affecting expected duration is particularly interesting in light of the results of Appendix B. In Appendix B we find substantial correlation between previous wages and wages obtained following the unemployment spell 
Table 1: Percentages of non-workers registered with the state employment agency (FES), and receiving benefit, by gender

\begin{tabular}{|l|l|l|l|l|l|l|}
\hline & \multicolumn{2}{|c|}{1994} & \multicolumn{2}{c|}{1995} & \multicolumn{2}{c|}{1996} \\
\hline & males & females & males & females & males & females \\
\hline $\begin{array}{l}\text { Non-workers registered } \\
\text { at FES }\end{array}$ & 6.7 & 11 & 5.5 & 13 & 6.5 & 8.3 \\
\hline $\begin{array}{l}\text { FES registrants receiving } \\
\text { benefit }\end{array}$ & 54.1 & 64.5 & 49 & 60 & 60.4 & 65.8 \\
\hline
\end{tabular}

Source: RLMS 1994-1996

Table 2: Job search strategies of the unemployed. Proportions using each method in month prior to RLMS interview

\begin{tabular}{|l|l|l|l|}
\hline Search Strategy & $\mathbf{1 9 9 4}$ & $\mathbf{1 9 9 5}$ & $\mathbf{1 9 9 6}$ \\
\hline Applied to state agency & .42 & .46 & .48 \\
\hline Applied to private agency & .13 & .12 & .11 \\
\hline Friends & .56 & .55 & .69 \\
\hline Relatives & .26 & .26 & .43 \\
\hline at enterprise & .47 & .42 & .50 \\
\hline Advertising & .26 & .30 & .37 \\
\hline
\end{tabular}

Source: RLMS 1994-1996

Table 3: Percentages of different labour force categories who would be considered "ILO"-unemployed individuals under our definition

\begin{tabular}{|l|l|l|l|}
\hline Self-definition & $\mathbf{1 9 9 4}$ & $\mathbf{1 9 9 5}$ & $\mathbf{1 9 9 6}$ \\
\hline "higher education student" & 21 & 17 & 23 \\
\hline "disabled, unable to work" & 16 & 16 & 10 \\
\hline "retired, not working" & 11 & 12 & 13 \\
\hline "maternity leave" & .6 & - & - \\
\hline "on leave for caring for small children" & .33 & - & - \\
\hline "housewife" & 15 & 16 & 19 \\
\hline "temporarily not working, looking" & 56 & 60 & 57 \\
\hline "temporarily not working, don't want to work" & 5 & 7 & 9 \\
\hline
\end{tabular}

Source: RLMS 1994-1996 
Table 4: Stock of working-age individuals in various states at date of RLMS interview, 1994-1996

\begin{tabular}{|l|l|l|l|l|l|l|}
\hline Labour Market Status & \multicolumn{2}{|c|}{1994} & \multicolumn{2}{|c|}{1995} & \multicolumn{2}{c|}{1996} \\
\hline & Males & females & males & females & males & females \\
\hline Currently working & 79 & 68 & 78.1 & 68 & 75.7 & 69.3 \\
\hline $\begin{array}{l}\text { Maternity leave or leave for caring } \\
\text { for children under 3 years }\end{array}$ & - & 6.3 & & 6.3 & - & 5.1 \\
\hline Paid leave & 1.1 & .7 & .8 & .8 & 1.0 & .5 \\
\hline Unpaid leave & .6 & .8 & .35 & .9 & .6 & .6 \\
\hline Not working & 19.6 & 24.3 & 20.8 & 24 & 22.8 & 24.5 \\
\hline $\begin{array}{l}\text { Proportion of those not working } \\
\text { who would like a job }\end{array}$ & 74.9 & 74.9 & 70.6 & 72.9 & 75.9 & 75.9 \\
\hline $\begin{array}{l}\text { Proportion of searchers amongst } \\
\text { those who want to work }\end{array}$ & 53.1 & 44.6 & 56.2 & 47.0 & 55.2 & 46.4 \\
\hline No. of observations & 2758 & 2760 & 2605 & 2594 & 2692 & 2552 \\
\hline
\end{tabular}

Source: RLMS (1994-1996) 
Table 5 Individual Characteristics and Unemployment in the RLMS

\begin{tabular}{|l|l|l|l|}
\hline & \multicolumn{3}{|c|}{$\begin{array}{l}\text { Unemployed as Percentage } \\
\text { of Individuals in Group }\end{array}$} \\
\hline Category & $\mathbf{1 9 9 4}$ & $\mathbf{1 9 9 5}$ & $\mathbf{1 9 9 6}$ \\
\hline Gender & 6 & & \\
Females & 6 & 6 & 7 \\
Males & 7 & 7 & 9 \\
\hline Age & & & \\
Under 21 & 12 & 12 & 15 \\
$21-29$ & 10 & 10 & 13 \\
$30-39$ & 6 & 6 & 7 \\
$40-49$ & 7 & 4 & 6 \\
$50-59$ & 3 & 5 & 6 \\
\hline Education Level & & & \\
University/institute & 5 & 4 & 5 \\
Technical/Medical & 6 & 6 & 7 \\
Vocational Secondary & 9 & 8 & 10 \\
Factory School & 6 & 6 & 7 \\
Professional Courses & 5 & 7 & 7 \\
Primary 1 & 7 & 7 & 8 \\
\hline Overall & 6.5 & 6.6 & 8.0 \\
\hline No. of Observations=3683 & \multicolumn{3}{|l}{} \\
\hline Sourc: RLMS, $1994-1966$
\end{tabular}

Source: RLMS, 1994-1996

1 Includes unfinished secondary education. 
Graph 1: Path of the Hazard Function over Elapsed Duration, search unemployed

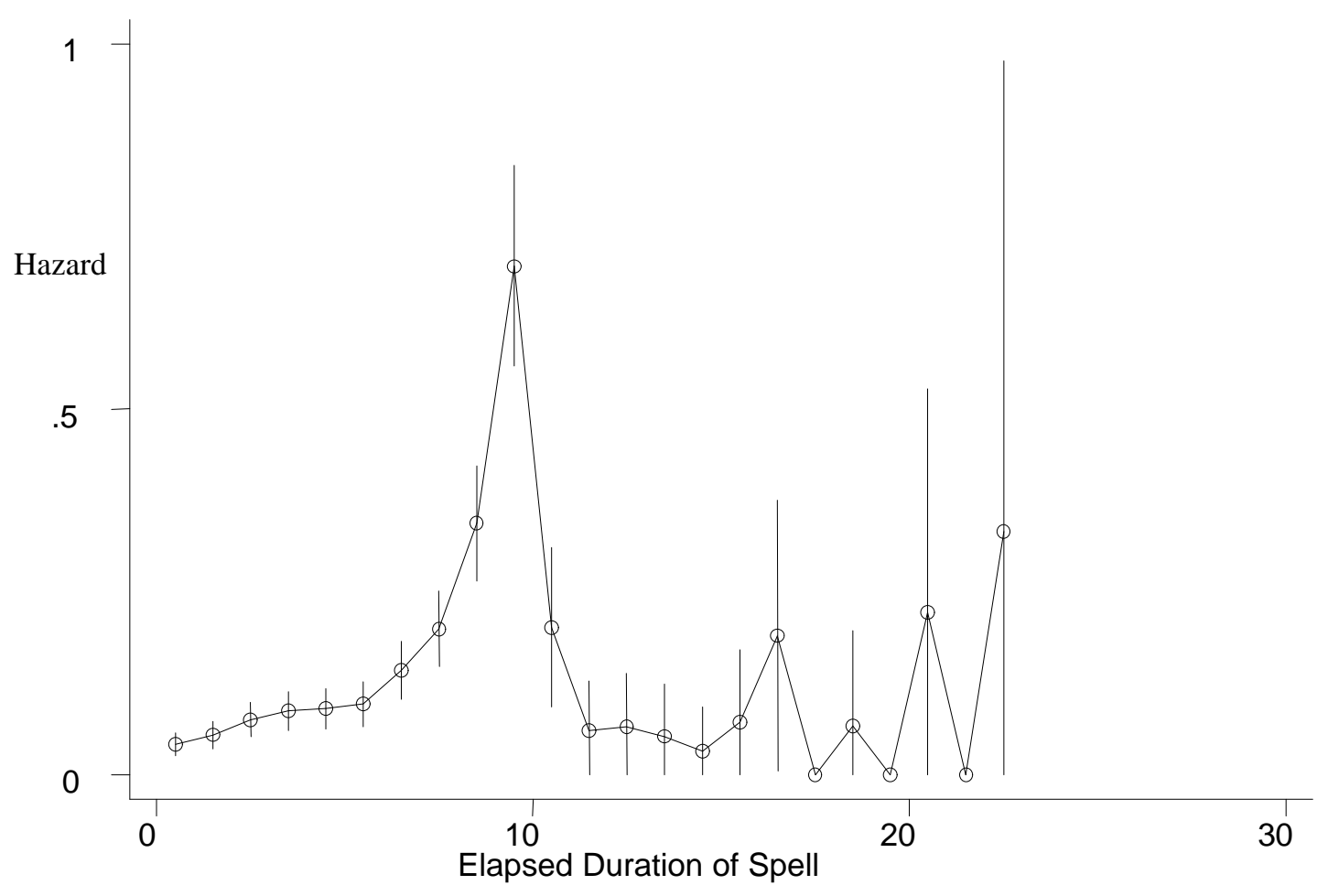

Source: Russian Longitudinal Monitoring Survey, 1994-1996 
Graph 2: Kaplan-Meier Survival Estimate Estimates, ILO

Unemployed

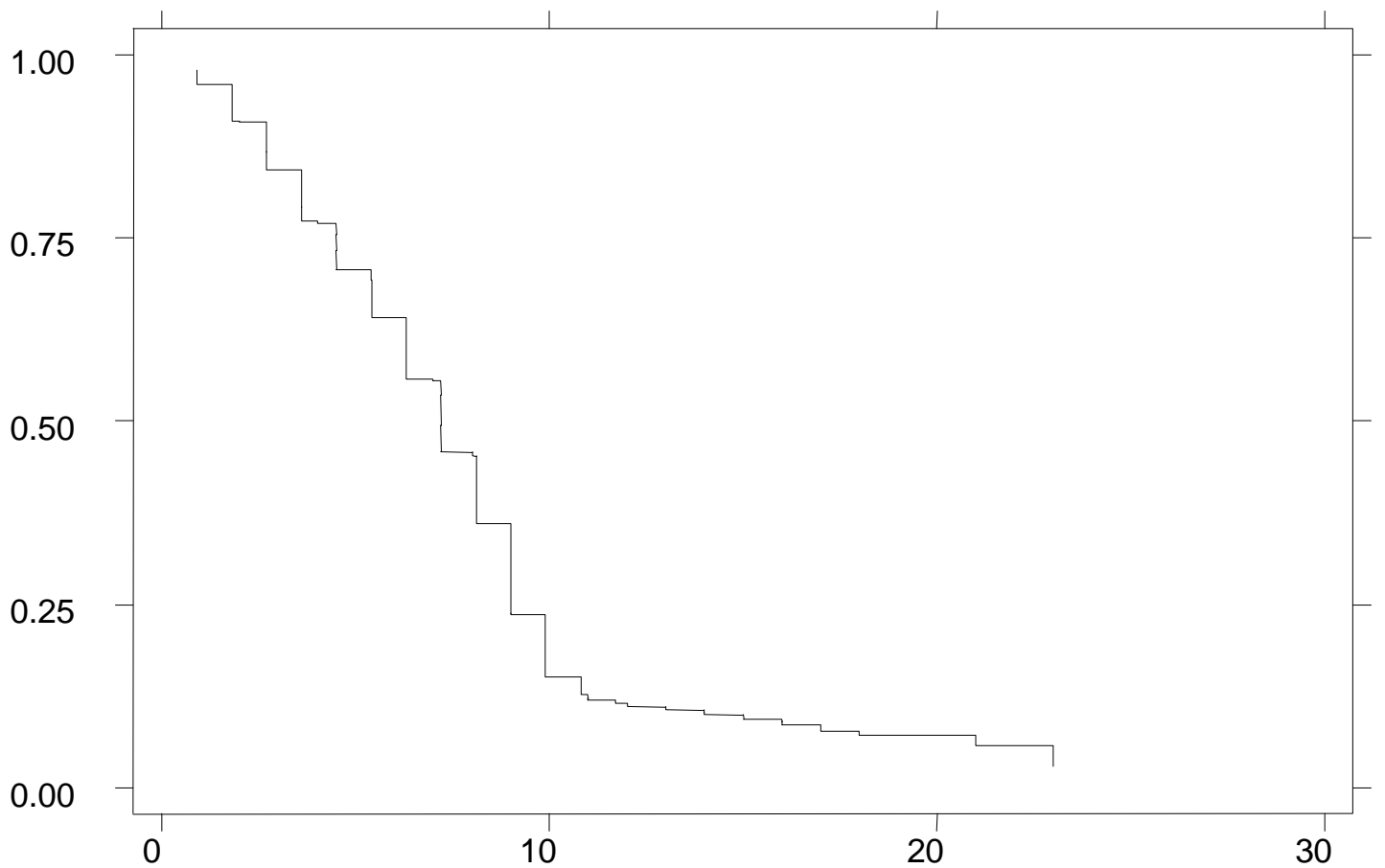

Elapsed Duration of Spell

Source: Russian Longitudinal Monitoring Survey, 1994-1996 
Graph 3: Representation of flows into and out of unemployment

Unemployment Flows, RLMS 1994-1996

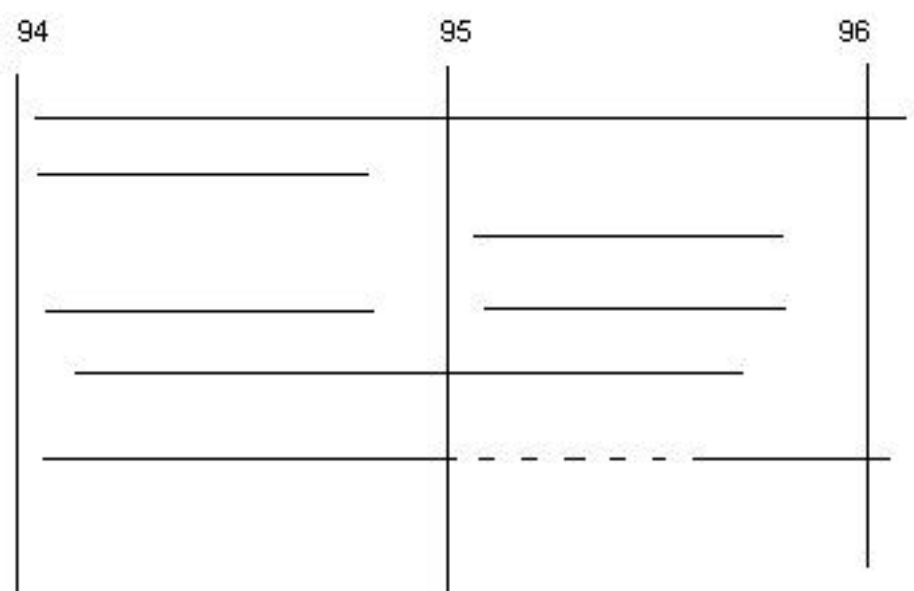


Table 6: Log Rank Tests of Differences in Hazard Rates of Selected Labour Market Segments

\begin{tabular}{|l|l|l|l|l|}
\hline Labour Force Grouping & \multicolumn{4}{l|}{ Probability Chi-squared } \\
\hline & ILO & No job & No Work & No Pay \\
\hline Age group & .72 & .67 & $.02 * * *$ & $.04 * * *$ \\
\hline Male/female & .32 & .77 & $.04 * * *$ & $.07 * *$ \\
\hline Married/not married & .38 & .47 & .22 & .64 \\
\hline Married female/unmarried, married male & .79 & .69 & .39 & .69 \\
\hline Married male/ unmarried, married female & .60 & .16 & .80 & .98 \\
\hline Previous occupation "Professional"/other & $.06 * *$ & $.03 * * *$ & $.03 * * *$ & $.04 * * *$ \\
\hline Higher education completed/ not completed & $0 \quad * * *$ & $0 \quad * * *$ & $0 * * *$ & $0 * * *$ \\
\hline Vocational education completed & .43 & .28 & .28 & .32 \\
\hline Federal Employment Service in town & .95 & .34 & .69 & .76 \\
\hline Lives in town of 2500 individuals or less & .99 & .30 & .57 & .58 \\
\hline Lives in Moscow, St. Petersburg metro areas & $.10 * *$ & $.04 * * *$ & $.07 * *$ & $.08 * *$ \\
\hline
\end{tabular}

Source: Russian Longitudinal Monitoring Survey, 1994-1996

$* * *$ significant at $5 \%$ level

$* * \quad$ significant at $10 \%$ level

* $\quad$ significant at $15 \%$ level

\footnotetext{
${ }^{1}$ Age groups are: Under 25, 25-29, 30-39, 40-49, above 50.
} 
Table 7: Piece-Wise Constant Hazard Specification of Distribution of Observed Durations

\begin{tabular}{|c|c|c|c|c|c|c|c|c|}
\hline & \multicolumn{2}{|l|}{ ILO } & \multicolumn{2}{|l|}{ No Job } & \multicolumn{2}{|l|}{ No Work } & \multicolumn{2}{|l|}{ No Pay } \\
\hline & $\begin{array}{l}\text { Coefficient } \\
\text { of influence } \\
\text { on hazard }\end{array}$ & s.e. & $\begin{array}{l}\text { Coefficient } \\
\text { of influence } \\
\text { on hazard }\end{array}$ & s.e. & $\begin{array}{l}\text { Coefficient } \\
\text { of influence } \\
\text { on hazard }\end{array}$ & s.e. & $\begin{array}{l}\text { Coefficient } \\
\text { of influence } \\
\text { on hazard }\end{array}$ & s.e. \\
\hline Gender & $.259^{* * *}$ & .14 & $.285 * * *$ & .16 & $.215^{* * *}$ & .12 & $.195^{*}$ & .12 \\
\hline Married & .101 & .13 & -.0347 & .16 & $-.216 * * *$ & .11 & $-.226 * * *$ & .10 \\
\hline $\begin{array}{l}\text { Completed Higher } \\
\text { Education }\end{array}$ & $.358^{* * *}$ & .18 & $.422 * * *$ & .18 & $.538^{* * *}$ & .17 & $.426^{* * * *}$ & .15 \\
\hline $\begin{array}{l}\text { Moscow St. } \\
\text { Petersburg }\end{array}$ & $.331 * * *$ & .15 & $.340^{* * *}$ & .15 & $.356^{* * *}$ & .15 & $.228 * * *$ & $\begin{array}{l}.13 \\
4\end{array}$ \\
\hline Aged less than 25 & -.055 & .14 & -.0274 & .52 & -.164 & .12 & -.184 & .11 \\
\hline $\begin{array}{l}\text { Aged less than } 29 \\
\text { (reference category } \\
\text { is those } 30-39 \text { ) }\end{array}$ & -.197 & .20 & -.239 & .19 & .00758 & .17 & -.0026 & $\begin{array}{l}.00 \\
1\end{array}$ \\
\hline Aged 40 and above & -.394 & .20 & $-.601 * * *$ & .20 & $-.534 * * *$ & .18 & $-.412 * * *$ & $\begin{array}{l}.17 \\
3\end{array}$ \\
\hline $\begin{array}{l}\text { Resident of town of } \\
<2500\end{array}$ & .071 & .14 & .0136 & .11 & $-.270 * * *$ & .12 & $-.238 * * *$ & .11 \\
\hline \multicolumn{9}{|c|}{ Piece-Wise Constant Hazards } \\
\hline $\begin{array}{l}\text { One to Three } \\
\text { Months }\end{array}$ & .0360 & & .0322 & & .0983 & & .124 & \\
\hline $\begin{array}{l}\text { Three To Six } \\
\text { Months }\end{array}$ & .0611 & & .0559 & & .0715 & & .0809 & \\
\hline $\begin{array}{l}\text { Six to Nine } \\
\text { Months }\end{array}$ & .151 & & .1336 & & .143 & & .159 & \\
\hline $\begin{array}{l}\text { Nine to Twelve } \\
\text { Months }\end{array}$ & .319 & & .240 & & .250 & & .279 & \\
\hline $\begin{array}{l}\text { Beyond } 12 \\
\text { Months }\end{array}$ & .0516 & & .0500 & & .0979 & & .129 & \\
\hline \multicolumn{9}{|c|}{ Unobserved Herterogeneity Term } \\
\hline Probability & .087 & & .91 & & .11 & & .89 & \\
\hline Log Likelihood & -567.67 & & -851.57 & & -866.75 & & -971.99 & \\
\hline $\begin{array}{l}\text { Number of } \\
\text { observations }\end{array}$ & 646 & & 756 & & 985 & & 1101 & \\
\hline
\end{tabular}

Source: Russian Longitudinal Monitoring Survey, 1994-1996

*** significant at $5 \%$ level

** significant at $10 \%$ level

* $\quad$ significant at $15 \%$ level 
Table 8: Comparison of Factors affecting durations, Weibull estimation

\begin{tabular}{|c|c|c|c|c|c|c|}
\hline & \multicolumn{3}{|c|}{ 1994-1996 Flow Sample } & \multicolumn{3}{|c|}{$\begin{array}{l}\text { 1994 Stock Sample of Non- } \\
\text { Workers }\end{array}$} \\
\hline & $\begin{array}{l}\text { Variable } \\
\text { mean }\end{array}$ & Coef. & s.e. & $\begin{array}{l}\text { Variable } \\
\text { Mean }\end{array}$ & Coef. & s.e. \\
\hline Aged less than 25 & .153 & -0.194* & 0.12 & .208 & $-1.00 * * *$ & .35 \\
\hline Aged 25 to 29 & .124 & -0.132 & 0.13 & .160 & $-.531 *$ & .36 \\
\hline Aged 30 to 39 & .374 & -0.126 & 0.11 & .317 & $-.856 * * *$ & .32 \\
\hline Aged 40 to 49 & .275 & -0.143 & 0.11 & .225 & $-.552 *$ & .33 \\
\hline Aged 50-59 (reference) & .072 & & & .090 & & \\
\hline Completed higher education & .192 & $-0.351 * * *$ & 0.07 & .366 & -.018 & .15 \\
\hline Gender (reference=female) & .443 & $-0.267 * * *$ & 0.11 & .532 & $-.473 * *$ & .26 \\
\hline Moscow St. Petersburg metro area & .091 & $-0.136^{*}$ & 0.09 & .063 & -.236 & .27 \\
\hline Natural log of Round V wage & & -0.031 & 0.03 & & n.a. & \\
\hline Round V wage unobserved & & -0.321 & 0.41 & & n.a. & \\
\hline Married & .714 & $-0.274 * * *$ & 0.10 & .690 & $-1.14 * * *$ & .26 \\
\hline Married and female & .321 & $0.397 * * *$ & 0.13 & .278 & $.89 * * *$ & .31 \\
\hline Rural & .160 & -0.021 & 0.08 & .130 & .222 & .20 \\
\hline Constant & & $3.013 * * *$ & 0.43 & & $5.78 * * *$ & .39 \\
\hline & & & & & & \\
\hline Number of subjects & & 756 & & & 663 & \\
\hline Number of failures & & 550 & & & 179 & \\
\hline $\mathrm{P}$ & & 1.619 & & & 1.08 & \\
\hline pr> Chi squared & & 0 & & & .0001 & \\
\hline
\end{tabular}


Table 9: Log-Logistic Specification of Distribution of Observed Durations

\begin{tabular}{|c|c|c|c|c|c|c|c|c|}
\hline \multirow[t]{2}{*}{ Labour Market Status } & \multicolumn{2}{|l|}{ ILO } & \multicolumn{2}{|l|}{ No Job } & \multicolumn{2}{|l|}{ No Work } & \multicolumn{2}{|l|}{ No Pay } \\
\hline & $\begin{array}{l}\text { Coefficient } \\
\text { of influence } \\
\text { on expected } \\
\text { duration }\end{array}$ & Se & $\begin{array}{l}\text { Coefficient } \\
\text { of influence } \\
\text { on expected } \\
\text { duration }\end{array}$ & Se & $\begin{array}{l}\text { Coefficient } \\
\text { of influence } \\
\text { on expected } \\
\text { duration }\end{array}$ & se & $\begin{array}{l}\text { Coefficient of } \\
\text { influence on } \\
\text { expected } \\
\text { duration }\end{array}$ & se \\
\hline Aged less than 25 & .143 & .11 & .0570 & .12 & .545 & .43 & .469 & .39 \\
\hline Aged 25-29 & .0628 & .13 & -.0826 & .10 & .285 & .19 & .283 & .17 \\
\hline Aged 30-39 & .0649 & .12 & -.0270 & .11 & .178 & .18 & .139 & .13 \\
\hline $\begin{array}{l}\text { Aged } 40-49 \text { (above } 50 \text { is } \\
\text { reference) }\end{array}$ & .0844 & .07 & -.0298 & .08 & .0613 & .10 & .054 & .07 \\
\hline Completed Higher Education & $-.191 * * *$ & .071 & $-.195 * * *$ & .095 & .0935 & .10 & $-.0653 * * *$ & .04 \\
\hline Gender & $-.0978 * * *$ & .033 & $-.0944 * * *$ & .041 & $-.212 * * *$ & .062 & $-.0735 * * *$ & .05 \\
\hline $\begin{array}{l}\text { Moscow St.Petersburg Metro } \\
\text { Area }\end{array}$ & .0333 & & $.0129 *$ & .072 & .0179 & & .0200 & \\
\hline Log of previous wage & .149 & .08 & .138 & .13 & .0713 & .14 & .0646 & .12 \\
\hline Previous wage unobserved & 2.60 & 1.94 & 2.177 & 2.01 & .879 & .91 & .760 & .61 \\
\hline Marital status & $-.142 * * *$ & .11 & $-.140 \quad * * *$ & .07 & $-.1010 * * *$ & .08 & $.020 * * *$ & $\begin{array}{l}.00 \\
7\end{array}$ \\
\hline Married and female & $.238 * * *$ & .085 & $.243 \quad * * *$ & .12 & $.134 \quad * * *$ & .10 & $.037 * * *$ & $\begin{array}{l}.00 \\
9\end{array}$ \\
\hline Resident of rural area & .0829 & .075 & .0938 & .10 & $.250 \quad * *$ & .15 & $.236 *$ & .16 \\
\hline Duration Dependence Parameter & 3.94 & & 1.66 & & .963 & & 1.01 & \\
\hline Number of observations & 646 & & 756 & & 947 & & 1101 & \\
\hline
\end{tabular}

Source: Russian Longitudinal Monitoring Survey, 1994-1996

*** Significant at $5 \%$ level

** Significant at $10 \%$ level

* Significant at $15 \%$ level 
Table 10: Weibull Estimates of Factors Affecting Durations

\begin{tabular}{|c|c|c|c|c|c|c|c|c|}
\hline & \multicolumn{2}{|l|}{ ILO } & \multicolumn{2}{|l|}{ No Job } & \multicolumn{2}{|l|}{ No Work } & \multicolumn{2}{|l|}{ No Pay } \\
\hline & $\begin{array}{l}\text { Coefficient of } \\
\text { influence on } \\
\text { expected } \\
\text { duration }\end{array}$ & s.e. & $\begin{array}{l}\text { Coefficient of } \\
\text { influence on } \\
\text { expected } \\
\text { duration }\end{array}$ & s.e. & $\begin{array}{l}\text { Coefficient of } \\
\text { influence on } \\
\text { expected } \\
\text { duration }\end{array}$ & s.e. & $\begin{array}{l}\text { Coefficient of } \\
\text { influence on } \\
\text { expected } \\
\text { duration }\end{array}$ & s.e. \\
\hline Aged less than 25 & -0.173 & 0.13 & $-0.194 *$ & 0.12 & 0.209 & 0.17 & 0.148 & 0.16 \\
\hline Aged 25 to 29 & -0.061 & 0.13 & -0.132 & 0.13 & 0.168 & 0.16 & 0.171 & 0.16 \\
\hline Aged 30 to 39 & -0.071 & 0.11 & -0.126 & 0.11 & 0.051 & 0.14 & 0.020 & 0.13 \\
\hline Aged 40 to 49 & -0.098 & 0.12 & -0.143 & 0.11 & -0.051 & 0.14 & -0.066 & 0.13 \\
\hline $\begin{array}{l}\text { Completed higher } \\
\text { education }\end{array}$ & $-0.254 * * *$ & 0.06 & $-0.351 * * *$ & 0.07 & $-0.206^{* * *}$ & 0.09 & $-0.270 * * *$ & 0.08 \\
\hline Gender & $-0.206^{* *}$ & 0.11 & $-0.267 * * *$ & 0.11 & $-0.477 * * *$ & 0.16 & $-0.367 * * *$ & 0.15 \\
\hline $\begin{array}{l}\text { Moscow St. Petersburg } \\
\text { metro area }\end{array}$ & -0.111 & 0.08 & $-0.136^{*}$ & 0.09 & -0.163 & 0.12 & -0.124 & 0.11 \\
\hline $\begin{array}{l}\text { Natural log of Round V } \\
\text { wage }\end{array}$ & -0.022 & 0.03 & -0.031 & 0.03 & -0.013 & 0.05 & -0.044 & 0.04 \\
\hline Round V wage unobserved & -0.176 & 0.38 & -0.321 & 0.41 & -0.153 & 0.55 & -0.481 & 0.52 \\
\hline Married & $-0.219 * *$ & 0.09 & $-0.274 * * *$ & 0.10 & $-0.342 * * *$ & 0.14 & $-0.221 * *$ & 0.13 \\
\hline Married and female & $0.236^{* *}$ & 0.12 & $0.397 * * *$ & 0.13 & $0.466^{* * *}$ & 0.18 & $0.362 * * *$ & 0.17 \\
\hline Rural & -0.104 & 0.08 & -0.021 & 0.08 & $0.172^{*}$ & 0.11 & 0.167 & 0.11 \\
\hline Constant & $2.735 * * *$ & 0.40 & $3.013 * * *$ & 0.43 & $2.405 * * *$ & 0.57 & 2.633 & 0.55 \\
\hline Number of subjects & 646 & & 756 & & 947 & & 1101 & \\
\hline Number of failures & 516 & & 550 & & 745 & & 864 & \\
\hline $\mathrm{P}$ & 1.742 & & 1.619 & & 1.019 & & 1.007 & \\
\hline Pr> Chi squared & 0.0068 & & 0 & & 0.0004 & & 0.0001 & \\
\hline
\end{tabular}

$* * *$ significant at $5 \%$ level

** significant at $10 \%$ level

* $\quad$ significant at $15 \%$ level 